\title{
Partycypacja społeczna dzieci - współczesna odsłona dyskursu; kontestacja i kontrdziałanie wobec społecznej ekskluzji dzieci
}

[...] zapatrzeni we własnq walkę, własnq troskę nie dostrzegamy go, jak dawniej nie dostrzegaliśmy kobiety, chłopa, ujarzmionych warstw i narodów [...]

Janusz Korczak

\section{STRESZCZENIE}

Artykuł przedstawia partycypację społeczną dzieci - rozumienie oraz charakter dyskursu naukowego w kontekście spostrzegania sytuacji dzieci jako dyskryminowanych społecznie w dostępie do różnych praw i aktywności społecznych i obywatelskich, w tym szczególnie prawa do uczestniczenia w decyzjach społecznych. Na tle analizy społecznej ekskluzji dzieci w minionych wiekach autorka pokazuje rozwój i zmianę w społecznym i obywatelskim statusie dzieci jaka dokonuje się w społeczeństwach demokratycznych. Wskazuje na podstawowe znaczenie Konwencji o prawach dziecka i innych dokumentów w konstruowaniu tej zmiany oraz w prezentacji, a także wyjaśnianiu współczesnego rozumienia zakresu i poziomu możliwej partycypacji społecznej dzieci. W artykule ukazano też pogłębione znaczenie idei partycypacji społecznej dzieci na tle teoretycznego dyskursu tej problematyki. Autorka ukazuje dynamikę i ewolucję podstaw

1 Ewa Jarosz, Wydział Pedagogiki i Psychologii, Uniwersytet Śląski w Katowicach, Polska, e-mail: ewa.jarosz@us.edu.pl, ORCID ID: https://orcid.org/0000-0002-3207-0148. 
teoretycznych owego dyskursu, wskazując na przekierowanie z koncepcji dziecka aktora społecznego, dziecka zdolnego do działania społecznego, jakie dominowały jeszcze na początku tego stulecia, na teorie demokracji liberalnej, teorie nierówności, partycypacji obywatelskiej, teorie polityczne, teorie zarządzania oraz teorię uznania. Efektem jest rozwijanie się aktualnego dyskursu o partycypacji społecznej dzieci oraz promowanie jej implementacji społecznej jako działań niwelujących dotychczasową dyskryminację społeczną dzieci.

\section{Słowa kluczowe:}

partycypacja społeczna dzieci, ekskluzja społeczna dzieci, dyskryminacja społeczna dzieci

\section{ABSTRACT}

The paper presents social participation of children - understanding of the idea and the character of the scientific discourse on it in the context of perceiving children as socially discriminated in their access to social and civic rights and activities, particularly the right to participate in social decisions. On the basis of analysis of social exclusion of children in the past centuries the Autor presents the change in social and citizen status of children that has been taking place in democratic societies. The Autor indicates on the crucial meaning of the Convention on the rights of the child and other documents in building this change and in explaining contemporary meaning of the idea and of the range and the level of possible participation of children. In the paper the very deep understanding of the idea of children's participation based on the analysis of theoretical concepts is also explained. The Autor presents the dynamics and evolution of the theoretical background of the discourse on children's participation and indicates on process of change: from theories of a child as a social actor and a child as able to act in social affairs, that dominated in last decades towards theories of liberal democracy, theories of inequalities, citizen's participation, political theories, theories of governance and the theory of recognition as current theories that are used in this discourse. Finally, the development of today's discourse on children's participation and the promotion of its implementation in social practice are seen as crucial factors in elimination and counteracting social exclusion of children.

\section{Keywords:}

social participation of children, social exclusion of children social discrimination of children 


\section{WPROWADZENIE}

Aktualny dyskurs w obszarze tematyki dzieciństwa w dużej mierze ukierunkowany jest na kwestię społecznej pozycji dziecka oraz dzieci jako grupy społecznej, jak podmiotowości dzieci w kontekście procesów demokratyzacji. Coraz częściej w dyskursie tym wybrzmiewa postrzeganie dotychczasowej sytuacji społecznej dzieci jako wielokontekstowego ich dyskryminowania oraz społecznej ekskluzji, a i w konsekwencji krytyki tradycyjnej relacji społecznej z dziećmi i kontestacji nierówności społecznych, jakich doświadczają dzieci w sensie ograniczania lub uniemożliwiania ich udziału w różnych sferach aktywności społecznych, także politycznych. Dyskurs porusza również kwestie odmawiania im różnych możliwości działania, decydowania czy oceniania w ramach tego, co składa się na szeroko rozumianą partycypację społeczną - inaczej ujmując - tzw. aktywne obywatelstwo. W ostatnich latach w literaturze światowej ma miejsce lawinowy wręcz wzrost liczby publikacji podejmujących różne aspekty tematu dyskryminacji, ekskluzji społecznej dzieci oraz braku ich uznania w kategoriach partycypacji społecznej i politycznej. Pomimo bowiem, iż idee partycypacji społecznej dzieci promowane są na gruncie międzynarodowym w szeregu artykułach różnych konwencji, kart czy rekomendacji lub w postaci bezpośrednich postulatów co do jej upowszechniania, to rzeczywistość społeczna dzieci daleka jest jeszcze od oczekiwań w tym zakresie. Aby dynamiczniej dokonywała się implementacja idei partycypacji dzieci, urzeczywistnianie praw dzieci do partycypacji w praktyce życia społecznego, powstaje wiele podmiotów - organizacji, fundacji i stowarzyszeń na poziomie krajowym i międzynarodowym stawiających sobie taki cal działalności.

W opracowań i ujęciach tematu partycypacji dzieci, jakie spotyka się w światowym dyskursie, pojęcie to rozumiane jest z jednej strony podobnie, a jednocześnie w bardzo odmienny sposób w różnych warunkach społeczno-kulturowych i politycznych (Liebel, 2017b; Perry-Smith i Thomas, 2010). Z tego powodu, jak podkreśla Manfred Liebel (2017b), najbardziej trafnym podejściem do tematu jest perspektywa międzykulturowa, która wymaga powstrzymywania się od binarnych podejść ocennych co do różnych koncepcji i praktyk partycypacji, tj. uznawania danych przejawów za lepsze czy gorsze, postępowe czy zacofane. Poza bowiem zasadniczymi uniwersalistycznymi ujęciami partycypacja dzieci przybiera różne postaci i realizowana jest różnymi praktykami.

Przestrzeń i wymiary partycypacji dzieci i młodzieży są wielorakie, a dyskurs o nich przypomina swoistą mozaikę tworzącą barwny i wielowymiarowy obraz. Obraz na dodatek wielokulturowy. Co przedstawia, co na nim wida - zależy od tego, z której strony na niego spojrzymy oraz jakich użyjemy „soczewek”. O roli 
podejść i „narzędzi” wykorzystywanych w przedmiotowym dyskursie traktuje poniższe opracowanie.

\section{OD „PRZEDMIOTU” ODDZIAtYWAŃ SOCJALIZACYJNYCH DO PARTNERA}

W historii społecznej dziecko spostrzegano przede wszystkim jako niepełnego człowieka, ułomnego, dzikiego, grzesznego, wymagające poskromienia, nieodpowiedzialnego, niegotowego, niedojrzałego do życia społecznego. Dziecko musiało dorastać do bycia człowiekiem i na tej drodze traktowano je jako biernego odbiorcę wpływów dorosłych. Wymagało „swoistej kwarantanny, zanim pozwolono mu wejść między dorosłych”, jak pisał Aries (1995, s. 236), lub, jak to brutalniej określała Alice Miller (1980), specjalnej tresury w postaci mniej lub bardziej restrykcyjnych, a wręcz reżimowych zabiegów i praktyk socjalizacyjnych.

Sytuacja dzieci pod względem charakteru relacji społecznych oraz opiekuńczowychowawczych zmieniła się dopiero w XIX wieku, pomimo że wcześniej występowały różnego rodzaju refleksje i praktyki nawołujące do innego traktowania dzieci; szanowania ich, dbania o nie ze względów interes społeczny lub dbałość o ich indywidualny rozwój (Jarosz, 2008). W XIX wieku zdecydowanie intensywniej i powszechniej zaczęto postulować nowe „traktowanie” dziecka. Podkreślano, że wymaga ono specjalnej opieki, wsparcia i odpowiednich warunków rozwoju. Szczególną rolę odegrali w tym względzie psychologowie oraz lekarze, wskazując na znaczenie odpowiednich warunków rozwoju i odpowiedniego traktowania dziecka dla jego powodzenia psychospołecznego w przyszłości. W tym czasie pojawiają się też głosy pedagogów i myślicieli, którzy owe nawoływania do dobrego traktowania dziecka argumentują ważnością i wartością dziecka jako osoby, jako istoty ludzkiej, podkreślając też ogromne znaczenie właściwych zabiegów wychowawczych oraz konieczność edukacji dzieci. Przy czym w zdecydowanej większości w tych postulatach akcentowano zysk społeczny, korzyści, jakie tego typu traktowanie dzieci niesie społeczeństwu, szczególnie w postaci ładu społecznego i społecznej dyscypliny, którą kształtuje powszechna edukacja (Milne, 2013). Jednakże pomimo rozwijania się pajdocentrycznego podejścia dziecko w sensie powszechnego spostrzegania społecznego widziane było jednak przede wszystkim jako jednostka „niegotowa” do udziału w społeczeństwie i niedojrzała do uczestnictwa społecznego (Jarosz, 2017). Nadal pod koniec XIX wieku dziecko pozostawało przedmiotem oddziaływań socjalizacyjnych i wychowawczych. Było „materiałem” do społecznego urobienia i kandydatem na uczestnika życia społecznego. Ogromny wpływ na te poglądy miała, jak wskazuje Maria 
Szczepska-Pustkowska (2011, s. 42 i nast.), rozwijająca się wówczas dynamicznie psychologia rozwojowa i dominujące w tym czasie stanowiska socjologiczne Spencera, Durkheima, a później dodatkowo Znanieckiego, którzy skonstruowali obraz dziecka w relacjach socjalizacyjnych jako przedmiotu zabiegów wychowawczych i socjalizacyjnych. W konsekwencji w powszechnym uznaniu pedagogiczną wartością były przede wszystkim: posłuszeństwo, podporządkowanie, uległość i karność dzieci. Prezentowanie własnego zdania, próby samodzielnego oddziaływania na rzeczywistość przez dziecko, czy też chęć decydowania o sobie surowo potępiano i tłumiono jako wyraz krnąbrności, buntu, bezczelności, wobec których należało stosować radykalne środki dyscyplinujące. W tym duchu udzielano więc rad wychowawczych w prasie i pedagogicznych „podręcznikach” (Miller, 1980).

Co istotne nie tylko z perspektywy indywidualnej, ale w konsekwencji także z perspektywy zbiorowej, ekskluzja dzieci z życia społecznego była społecznym standardem i niemal nikt nie kontestował tej sytuacji. Do wyjątków należała na przykład Charlotta Perkins Gillman, autorka słynnego feministycznego manifestu Herland, która w 1900 roku w innej swojej pracy pt. Concerning children wskazywała na dyskryminację dzieci jako grupy społecznej, nazywając je w tym sensie grupą mniejszościową, pisząc: „Rozważając sytuację dzieci, musimy pamiętać, że stoi przed nami permanentna grupa społeczna, czasami większa niż populacja dorosłych. Ale jako członkowie społeczeństwa, nie otrzymują one niemal żadnej uwagi i nie są rozpoznawane jako należące do społeczeństwa” (podaję za: Rosen i Twamley, 2018). W tej wczesnodwudziestowiecznej rzeczywistości społeczno-pedagogicznej dziecka, dziecka ,jeszcze nie-człowieka”, dziecka „materiału do urobienia”, dziecka „przedmiotu zabiegów wychowawczych”, pojawia się ze swoimi poglądami Janusz Korczak, który wyraziście zwraca uwagę na powszechne społeczne dyskryminowanie dziecka przez dorosłych. Korczak mówi o dziecku jako „już człowieku”, zabiega o szacunek dla niego, o uznanie jego wartości społecznej, o uznanie głosu dziecka. Co więcej, zabiegał o uznanie dziecka jako obywatela, jako członka wspólnoty uprawnionego do decydowania, do życia społecznego, a nawet do samozarządzania - „Dziecko - już mieszkaniec, obywatel i już człowiek. Nie dopiero będzie, a już [...]”, pisał (Korczak, 1928). Musiały minąć jednak długie dekady, by ta korczakowska myśl o społecznym udziale i społecznej podmiotowości dziecka zyskała uznanie i popularność. Bowiem dopiero w końcówce XX wieku na arenę naukowej, ale też do społeczno-politycznej refleksji o dziecku wkraczają koncepcje dziecka jako aktora społecznego, jako konstruktora swojego i otaczającego go świata oraz postrzegania dzieci jako uczestników życia społecznego (Prout, James, 1997). Rozwija się „,nowa socjologia” dziecka (Corsaro, 1997, Jenks, 2008), która promuje nową pozycję dziecka 
w układzie społecznym, transformuje rozumienie dziecka z przedmiotu działań wychowawczych i socjalizacyjnych w podmiot społeczny i kulturowy. Badacze nowej socjologii dziecka i niektórych nurtów pedagogiki (emancypacyjnej, antyautorytarnej) wskazują wówczas na konieczność innego podejścia do dziecka. Akcentowana jest jego podmiotowość i konieczność wspierania go w tworzeniu przez nie samo, w swoistej autonomii i wolności, własnego świata i własnego życia w relacji równości z dorosłymi i uznania świata dziecka i dzieci przez dorosłych (Śliwerski, 2003). W rozwijającym się dyskursie o „nowym dziecku” podkreślana jest konieczność rekonstrukcji i redefinicji dzieciństwa i jego kultury, z wyraźnym postulatem, by poznawać dzieciństwo przez wchodzenie w świat dzieci „ich oczami”, przez analizowanie relacji dziecka o sobie i o świecie (Jenks, 2008). Równolegle do tego nurtu rozwija się dyskurs o sytuacji dzieci jako osób i grupy dyskryminowanej społecznie. „Dzieci pozostają nadal ostatnią z rozległych grup społecznych, którą powszechnie dotyka społeczna dyskryminacja” pisał w jeszcze latach siedemdziesiątych XX wieku Jonh Holt (1974). Także w kontekście postępującej demokratyzacji życia oraz walki o demokrację w innych państwach, w Europie, obu Amerykach i Australii, dyskutuje się o dostępie dzieci do zasobów i dóbr społecznych oraz procesów i decyzji społecznych, a także do usług społecznych (zob. Freire, 2005) W efekcie rozwija się dyskurs o dziecku jako równoważnym partnerze, a relację między dorosłym a dzieckiem postuluje się jako relację wymiany pomiędzy równie ważnymi stronami z nieokreśloną jednoznacznie pozycją autorytetu (Szczepska-Pustkowska, 2011).

\section{KONIEC Z DYSKRYMINACJĄ DZIECI? PARTYCYPACJA SPOŁECZNA „MAŁYCH I MŁODYCH” - SENS I ROZWÓJ KONCEPCJI}

Współczesne rozumienie koncepcyjne dziecka to obraz uczestnika wspólnoty rodzinnej, szkolnej, środowiskowej, społecznej, państwowej czy regionalnej. Dzieci - młodzi ludzie - „stały się” podmiotami własnego życia, ale i życia społecznego (Lister, 2009), są widziane jako ulokowani we wspólnotach społecznych na partnerskich zasadach równouprawnienia (Śliwerski 2007). Relacja dzieci i dorosłych to relacja, w której obie strony współistnieją, współuczestniczą, współdziałają, współpracują i współkonstruują - jak wylicza Maria Szczepska-Pustkowska (2011) - w równości, we wzajemnym szacunku oraz równouprawnieniu. W następstwie tego w praktyce społecznej młodzi ludzie, wcześniej niezauważani lub bagatelizowani, obecnie traktowani są jako adwokaci swych interesów, jako aktorzy społeczni i aktywiści społeczni, jako recenzenci decyzji, które ich dotyczą, a także 
jako badacze własnej rzeczywistości (Wyness, 2012; Toots et al. 2014; Dahl; 2014). Partnerstwo staje się w tym ujęciu zasadniczą cechą relacji pomiędzy światem dzieci i dorosłych, pomiędzy nimi zaś jest symetryczną. Dokonuje się zmiana relacji między dorosłymi a dziećmi; postawa protekcji ustępuje partycypacji. Dzieci są włączane w decyzje społeczne, a nawet polityczne, a także w inne działania społeczne (Lansdowne, 2010). Postawa „dla dzieci” ustępuje miejsca postawie „z dziećmi”. I to jest w zasadzie najkrótsza definicja tego, czym jest partycypacja społeczna dzieci. To działanie i organizowanie rzeczywistości oraz rozwiązywanie różnego rodzaju problemów wspólnie z dziećmi, w dialogu z nimi, w partnerstwie.

Zapewnienie partycypacji dzieci w formie społeczno-politycznego przesłania (manifestu) przedstawiono w Konwencji o prawach dziecka z 1989 roku. Tu przede wszystkim istotny jest Artykuł 12, który określa prawo dzieci do swobodnego wyrażania własnych poglądów w sprawach ich dotyczących oraz zobowiązuje dorosłych do przyjmowania tych poglądów z należytą powagą, stosownie do zdolności dziecka. Kolejne artykuły, tj. 13, 14, 15, 16 i 17, uszczegóławiają ideę partycypacji społecznej dzieci, jako prawo do swobodnej wypowiedzi, prawo do (odpowiedniej) informacji, prawo do swobody myślenia, sumienia i wyznania, prawo do swobodnego zrzeszania się, prawo do prywatności oraz prawo do dostępu do informacji medialnych. Obok tych artykułów dla rozumienia praw partycypacyjnych istotny jest także artykuł 3 Konwencji, który mówi o tzw. najlepszym zabezpieczeniu interesów dziecka. Zwraca się uwagę, że poprzez te wszystkie artykuły w Konwencji zaakcentowano prawo dzieci do samostanowienia, ale jednocześnie określono ich status jako pełnoprawnych obywateli, a samą partycypację społeczną dzieci uczyniono jednym z podstawowych wymiarów ich funkcjonowania, ale też jednym z „warunków ich właściwego rozwoju” (Wyness, 2012, s. 234).

Poza Konwencją, jako na uszczegółowienie jej wykładni co do idei partycypacji dzieci, należy spojrzeć na Komentarz Ogólny Komitetu Praw Dziecka nr 12 z 2009 roku zatytułowany The right of the child to be heard /CRC/C/GC/12 (Prawa dziecka..,2015). Wyjaśnia się w nim, że państwa powinny z jednej strony zachęcać dzieci do formułowania i wyrażania swoich poglądów, a z drugiej stwarzać im ku temu rzeczywiste warunki i możliwości. Podkreśla się, że poglądy i stanowisko wyrażane przez dzieci mogą znacząco wzbogacić perspektywy i doświadczenia dorosłych i powinny być brane pod uwagę przy podejmowaniu decyzji, przy budowaniu rozwiązań politycznych oraz przy przygotowywaniu ustaw czy sposobów działania, jak też przy ewaluacji działań. Uzupełnieniem wyjaśnień co do istoty partycypacji dzieci jest nota zawarta w Komentarzu nr 5 Komitetu Praw Dziecka z 2003 roku o wprowadzaniu w życie Konwencji o prawach dziecka, w którym wskazano na konieczność rozwijania bezpośrednich relacji rządów państw z sze- 
rokimi grupami dzieci w celu ustalania ich poglądów oraz kreowania odpowiedniej polityki w różnych sektorach, przy czym podkreślono w nim, że chodzi o właśnie bezpośrednie relację, a nie przez media czy organizacje pozarządowe (Prawa dziecka..., 2015). Tym samym wyraźnie wskazano na rozumienie oraz potrzebę realizacji praw partycypacyjnych dzieci nie tylko w kontekście indywidualnym czy w kontekście wąskich grup dzieci i młodzieży funkcjonujących w jakichś instytucjach czy środowiskach, ale też w znaczeniu zbiorowym. Ten zresztą wymiar rozumienia i analizowania partycypacji dzieci w aktualnym dyskursie zdaje się przeważać (Thomas, 2007; Liebel, 2017).

Wiele jest w literaturze przedmiotu wyjaśnień i interpretacji sensu i zawiłości partycypacji przedstawianej jako prawo i postulat społeczno-polityczny w różnych dokumentach. Autorzy koncentrują się często na artykule 12 Konwencji, (np. Lundy 2007, Lansdowne 2018). Warto jednak pamiętać o pozostałych artykułach Konwencji oraz o wykładniach sensu partycypacji lub, jak określają to niektórzy, aktywnego obywatelstwa dzieci (Cockburn, 2013). Jeśliby jednak spróbować wyeksponować różne wymiary, które składają się na sens oraz rozumienie, czym jest i przede wszystkim jakie przejawy ma (może przybierać) partycypacja dzieci, o których mówią wymienione wyżej i inne jeszcze dokumenty (np. liczne tematyczne rekomendacje Rady Europy), a także rozważania i teksty przedmiotowego dyskursu, to można by, moim zdaniem, zaproponować następujący zbiór głównych przejawów partycypacji społecznej dzieci:

- dostęp do odpowiednio przygotowanej informacji;

- prezentowanie opinii i ekspresja poglądów;

- tworzenie własnej relacji o rzeczywistości (tworzenie informacji, tworzenie tekstów, sztuki itp.);

- udział w decydowaniu o działania, rozwiązaniach w sprawach bezpośrednio lub pośrednio odnoszących się do sytuacji dzieci;

- współzarządzanie lub samozarządzanie rzeczywistością ( jej określonymi polami);

- udział w ocenie działań i rozwiązań podejmowanych na rzecz dzieci, udział w krytyce tychże;

- wspólnotowość dziecięca, zrzeszanie się, stowarzyszanie się (ruchy i organizacje tworzone i zarządzane przez dzieci);

- działanie na rzecz wspólnego dobra, na rzecz innych oraz na rzecz środowiska społecznego i naturalnego;

- współudział w badaniu problemów i sytuacji oraz różnych wymiarów życia dzieci. 
Te przejawy rozumiane są jako możliwe do urzeczywistniania zarówno na poziomie indywidualnym (konkretnego dziecka, konkretnej grupy dzieci, np. w szkole), jak i zbiorowym, w którym podmiotem partycypacji są szerokie grupy i zbiorowości dzieci. Ponadto należy już w tym miejscu zauważyć, choć wątek będzie rozwinięty później, że w zbiorowym sensie rozumienia partycypacja młodych ludzi wchodzi w wymiar politycznej partycypacji, o czym piszą wprost niektórzy autorzy (zob. Thomas, 2009).

Jak więc widać w partycypacji, co podkreśla Roger Hart (2009), nie chodzi tylko (jedynie) o wysłuchiwanie dzieci, o uwzględnianie ich głosu w procesach decydowania i zarządzania rzeczywistością, jak często się to rozumie. Hart, wyjaśniając sens partycypacji społecznej dzieci, podkreślał, że w głębokim rozumieniu partycypacji tak naprawdę chodzi o wszystkie sytuacje, kiedy dzieci współpracują z innymi dziećmi oraz (lub) z dorosłymi w celu podjęcia jakichś decyzji ale także w celu zaplanowania i realizowania wspólnych aktywności, począwszy od wspólnego wybudowania miejsca do zabawy, a skończywszy na wspólnym wypracowaniu rozwiązań polityki państwa w sferze edukacji, zdrowia czy polityki społecznej, które przecież dotyczą dzieci (Hart, 2009). Podobnie rzecz ujmują inni badacze, zwracając uwagę na wielopostaciowość partycypacji. Na przykład Percy-Smith i Thomas (2010) także podkreślali, że partycypacja dzieci to nie tylko rozmawianie, że nie chodzi tylko o „głos” dzieci, ale także o wspólne z nimi działanie z nimi. Jak widać, rzeczywista partycypacja - jej głęboki sens, zdąża do partnerstwa i współdziałania w możliwie szerokich obszarach życia i w takiej postaci jej urzeczywistnianie wymaga bardzo głębokiej transformacji formalnych struktur państwa i struktur lokalnych w stronę zapewnienia równego, stałego i systematycznego współudziału dzieci w decyzjach i działaniach, ich współzarządzania daną rzeczywistością.

Roger Hart (1997) krytycznie analizując swego czasu stan urzeczywistniania partycypacji dzieci, zauważał wiele nieprawidłowości i podkreślał, że minie wiele czasu, zanim w poszczególnych krajach nastąpią rzeczywiste zmiany w podejściu do partycypacji dziecięcej w życiu obywatelskim i zanim zacznie się ona w pełni realizować. Już wcześniej Hart (1992) podkreślał, że prawdziwa partycypacja dzieci opiera się na kilku fundamentalnych warunkach:

- świadomość i rozumienie intencji projektu /zdania/ działania przez dzieci;

- dobrowolności ich udziału lub własna inicjatywa co do jego powstania;

- rozumienie przez młodych ludzi zasad swojego udziału w wyrażaniu opinii, w podejmowaniu decyzji;

- ważność udziału i faktyczna mocy wpływu; 
- rzeczywiste reprezentowanie rówieśników przez struktury reprezentacyjne jeśli o nich mowa (rady, komitety), przez odpowiedni ich wybór;

- duży stopień swobody co do formy i szczegółowych aspektów wypowiedzi.

W tym miejscu należy podkreślić wagę kwestii wielokulturowości w przedmiotowym dyskursie oraz rozumienia, czym jest partycypacja, co oznacza to pojęcie, a wręcz jak nazywana jest partycypacja, jakich używa się wobec niej i jej przejawów określeń, jak jest zróżnicowana w różnych warunkach kulturowych. Jak wskazują niektórzy badacze, nawet sam termin „partycypacja” w niektórych kulturach nie ma swojego odpowiednika, a zjawiska nazywane w języku zachodniego świata partycypacją, znajdują tam zupełnie inne określenia (Liebel, 2017b).

\section{EKSKLUZJA I DYSKRYMINACJA DZIECI JAKO AKTUALNE IDEOWE, TEORETYCZNE I TELEOLOGICZNE KONTEKSTY PARTYCYPACJI DZIECI}

W pierwszych dekadach rozwoju dyskursu o partycypacji dzieci, tj. od lat 70. XX w. i po uchwaleniu Konwencji o prawach dziecka, podstawowym kontekstem ideowo-teoretycznym były wspomniane wyżej koncepcje w ramach tzw. nowej socjologii dziecka, pokazujące dziecko jako aktora społecznego, jednostkę kreującą swoją rzeczywistość oraz jako aktywnego uczestnika życia społecznego. Zwracano także uwagęte koncepcje społeczno-pedagogiczne (antyautorytarne), które podkreślały kompetencje dziecka do decydowania, działania i zarządzania własnym rozwojem, jak i te, które akcentowały podmiotowość dziecka oraz znaczenie partycypacji dla rozwoju owej podmiotowości, jak i inne korzyści rozwojowe, które dzieci lub inni (społeczeństwo) odnoszą wskutek partycypacji. Ważnym podłożem rozważań o partycypacji była też sama idea - koncepcja praw dziecka jako definiująca sprzyjające rozwojowi dziecka warunki oraz pedagogiczne idee wyzwolenia, emancypacji, w tym szczególnie pedagogika Paulo Friere’a (Thomas, 2012). Innymi słowy, w pierwszych dekadach rozwoju dyskursu o partycypacji dzieci dominowały te konteksty teoretyczne, które skupione były na indywidualnej perspektywie dziecka zarówno w uwarunkowaniach, jak i w argumentach na rzecz partycypacji. Odwoływano się głównie do zdolności dziecka, korzyści rozwojowych, w tym rozwoju podmiotowości, uczenia się aktywnego obywatelstwa, lepszego aktywne obywatelstwa w dorosłości itp. Podkreślano też konteksty teleologiczne (znaczeniowe), w których partycypacja dzieci widziana była przede wszystkim jako droga do osiągania owych wartości (rozwoju podmiotowości, postaw aktywnego obywatelstwa).

Obecnie, jak zauważa Nigel Thomas (2012), mniej więcej od 2006 roku dynamicznie rozwijają się próby użytkowania szerszych ujęć teoretycznych w kon- 
struowaniu koncepcyjnej obudowy partycypacji społecznej dzieci. Badacze i poszczególne narracje znacznie częściej sięgają do teorii społecznych i politycznych. W ten sposób, jak wskazuje Thomas (2012), źródłami inspiracji w rozważaniach i ujęciach partycypacji stają się coraz częściej teorie demokracji liberalnej - jak w przypadku Toma Cockburna (2010), teorie rządzenia i zarzadzania - jak czynią to Therese O’Tole i Richard Gale (2008) oraz Kay Tisdall (2010), teorie przestrzeni - jak u Grega Maniona (2010), teorie dialogu społecznego - jak ujmują to Ann Graham i Robyn Fitzgerald (2010), a także teorie zmiany społecznej oraz ogólne teorie obywatelstwa i partycypacji społecznej. Jako istotne dla kształtowania się dyskursu, wymienia się też teorie metodologiczne z obszaru participatory action research , którymi inspiruje się np. Barry Percy-Smith (2010). Sam Thomas (2007, 2012) przedstawia w tym względzie jako propozycję rozpatrywania partycypacji dzieci koncepcje polityczne Marion Young oraz Pierre’a Bourdieu, a także jako szczególnie przydatną - teorię uznania w wydaniu Axela Honnetha. Można zauważyć, iż w obecnym dyskursie o partycypacji dzieci silnie pojawiają się odwołania także do innych ogólniejszych stanowisk teoretycznych zawartych w haśle „walki o uznanie”, jak na przykład do Charlesa Taylora, Nancy Fraser (Fitzgerald et al., 2010; Thomas 2007, 2012) .

Widać więc, że obecny dyskurs o partycypacji dzieci dryfuje w stron, tych teorii społeczno-politycznych, które urzeczywistnianie demokracji, aktywnego obywatelstwa oraz partycypacji społecznej stawiają w aksjologicznym centrum. Wartości zasadnicze, do jakich się nawołuje, dotyczą równości dzieci w dostępie do wszelakich zasobów oraz procesów decydowania i zarządzania, do praw i działania. Demokracja i jej urzeczywistnianie poprzez niwelowanie nierówności, walkę z dyskryminacją oraz szeroką inkluzję stanowią więc główny wymiar teleologiczny tego dyskursu.

Taki wyraźny zwrot wynika - co podkreśla - Manfred Liebel (2017a) - ze słabej ekspozycji perspektywy dyskryminacji ze względu na wiek. Jego zdaniem nie była ona wcześnie specjalnie widoczna ani w debatach z nurtu praw człowieka, ani nawet w samej Konwencji, z 1989 roku. Jego zdaniem to współczesna rzeczywistość, różnego rodzaju zjawiska spowodowały, że rozmyły się granice pomiędzy dorosłością a dzieciństwem w tradycyjnych kryteriach ich rozróżniania, tj. takich jak: odpowiedzialność, obowiązki uczenia, praca, kompetencje, umiejętność użytkowania dóbr (np. nowych technologii) czy dojrzałość społeczno-kulturowa. Dzisiaj, zdaniem Liebla, rozróżnianie dorosłych od dzieci w tym świetle rozmywa się, podział nie jest już tak kategoryczny i to powoduje wzmacnianie dyskursu o partycypacji dzieci jako należnej z perspektywy idei równości, demokracji i społeczeństwa obywatelskiego. 
W świetle wykorzystywania teorii społecznych i politycznych w obecnym dyskursie o partycypacji dzieci coraz bardziej wybrzmiewają w nim, w kategoriach ukazywania sensu i znaczenia partycypacji dzieci, takie terminy/pojęcia, jak: inkluzja, partnerstwo, współdziałanie, współzarządzanie, dialog społeczny, społeczne uznanie. Dzisiaj praktycznie zdominowały one odwoływanie się do wcześniejszych „idei” dziecka aktora społecznego, do podmiotowości dziecka, do jego zdolności w zakresie wyrażania opinii i podejmowania decyzji. Oczywiście nie powoduje to, że dawniejsze konteksty i terminologia „uprawiania” dyskursu o partycypacji dzieci są nieaktualne. Partycypacja dzieci nadal jest spostrzegana jako niemal zasadnicza płaszczyzna rozważań o przestrzeganiu praw dzieci oraz o działaniach w zakresie ochrony dzieci i ograniczania różnych problemów, które ich dotyczą, a także zapewniania im odpowiednich warunków rozwoju i ogólniej tzw. dobrostanu (child well-being) i poczucia podmiotowości. Obecność i silniejsze dziś wybrzmiewanie teorii społeczno-politycznych wraz z ich pojęciami i kategoriami w dyskusjach o partycypacji oznacza przede wszystkim przesunięcie w te konteksty teoretyczne akcentu, a nie całkowite zaniechanie odwoływania się do wcześniejszych ujęć teoretycznych i teleologicznych.

W świetle takiego obrazu partycypacji dzieci warto zwrócić uwagę na jeszcze jeden aspekt. Koncepcja partycypacji dotyczy dzieci zarówno w sensie indywidualnym, jak i zbiorowym. To znaczy, że - upraszczając tu na chwilę rozumienie - prawo dzieci do bycia wysłuchanym, do udziału w życiu społecznym i politycznym jest w kontekście przytoczonych koncepcji społeczno-politycznych prawem grup i zbiorowości dzieci od najmniejszych, jak np. klasa szkolna, grupa dzieci w sąsiedztwie, przez większe, jak zbiorowość dzieci w środowisku lokalnym, po całe populacje dzieci w społeczeństwie, w państwie. W świetle teorii społeczno-politycznych jako zaplecza rozumienia głębokiego sensu partycypacji dzieci powinny być traktowane przez państwo jako grupa społeczna czy zbiorowość o możliwie demokratycznym udziale, wpływie na ogólne decyzje podejmowane w kwestiach, które mogą ich dotyczyć. Jak niektórzy (Thomas, 2007) dodaj - także w przyszłości. Dzieci są rozległą grupą, której opinii należy wysłuchać i które jako grupa powinny brać udział w procesach decydowania w sprawach dla nich istotnych (Taylor, Percy-Smith, 2008) ale też jako kreatorzy życia społecznego i kulturalnego. To oznacza kilka wymiarów implementacyjnych. Po pierwsze, należy dążyć do pozyskania poglądów dzieci wypowiadających się zbiorowo, do konsultowania różnych decyzji z grupami dzieci oraz do poszanowania i uwzględniania ich opinii czy propozycji w procesach decydowania oraz projektowania i realizacji programów (Liebel, 2017). Poszanowanie partycypacji dzieci w tym kontekście będzie oznaczało też, że w podejmowanych w polityce w różnych 
obszarach ustaleniach, które dotyczą aktualnie lub potencjalnie dzieci jako zdefiniowanej grupy, to najlepszy interes dzieci, ich dobro musi być zasadniczym kryterium. W praktyce oznacza to po pierwsze, że jeśli w jakimś obszarze w grę wchodzi interes większej liczby dzieci, wówczas zarządzający instytucjami, urzędami, organami samorządowymi czy państwowymi powinni stworzyć przestrzeń i mechanizmy dające wystarczającą szansę udziału dzieci w tych działaniach czy rozwiązaniach , decydowania o nich oraz monitorowania wykonania. Po drugie, rozumienie partycypacji dzieci w kategoriach społeczno-politycznych jako grupy i zbiorowości oznacza również uznanie ważności i wartości ich głosu oraz niedyskryminowanie pod tym względem ich poglądów oraz form i środków ich prezentowania. To znaczy, jak zauważają Taylor i Percy-Smith (2008), że dorośli powinni powstrzymać się od interweniowania czy deprecjonowania tego, jak młodzi ludzie wyrażają swoje opinie, prezentują swoje zdanie czy oceny. Młodzi ludzie chcą artykułować swoje wartości przez własne akcje i przez własny wybór tego, o czym się wypowiadają, co ich interesuje, co chcą zrobić. Chcą też decydować o tym, kiedy i jak zareagują. Paradoksem jest to, jak zauważa Virginia Morrow (2005), że w sytuacjach partycypacji, jakimi są spontaniczne akcje organizowane przez samych młodych, dorośli popadają w panikę i często widzą w tym niebezpieczne „klimaty” buntu czy anarchii. W efekcie młodzi ludzie są zniechęcani do takich aktywności i trudnych dla dorosłych form partycypacyjnych, a wręcz spotykają ich za to restrykcje.

Partycypacja oznacza także, na co zwracał uwagę w Komentarzu Ogólnym nr 12 Komitet Praw Dziecka, realizowanie prawa dzieci jako grupy społecznej do informacji, to, że nie wolno ograniczać młodym ludziom dostępu do informacji o wszystkich sprawach ich dotyczących lub o sprawach, które w dużej mierze się do nich odnoszą. Co ważne, informacja ta powinna mieć odpowiednią postać - dostosowaną do możliwości rozwojowych dzieci. PAtrząc z drugiej strony, chodzi też o dostęp dzieci do tworzenia informacji, o umożliwienie im tworzenia i prezentowania własnej relacji o rzeczywistości i upubliczniania jej.

Co więcej odwołanie się do kontekstu społeczno-politycznego partycypacji oznacza uznanie kultury wytwarzanej przez młodych ludzi, ich sposobu na aktywność społeczną, i ich zjawisk społecznych i wytworów jako wkładu w ogólnospołeczną kulturę. Młodzi ludzie, jak podkreślał już dawno Roger Hart (1992, 2005), są w stanie już stosunkowo wcześnie sami tworzyć i organizować życie społeczne. Jego zdaniem ten właśnie obszar wymaga uważnego zbadania i opisania. Dzieci aktywnie konstruują swoje wzajemne relacje, wartości i wzory kulturowe, kody i przekazy. Testują je i adaptują do stylu swego funkcjonowania, dokonują decyzji i wyborów społecznych, podejmują wspólne aktywności i wzajemnie się kontro- 
lują, inspirują i organizują. Ich nieformalne działanie społeczne to też partycypacja. Ta nieformalna codzienna aktywność dzieci, zjawiska ich współdziałania ze sobą i z dorosłymi, relacje społeczne, jakie są udziałem zbiorowości dzieci, grup dzieci na co dzień i jakie odbywają się w naturalny sposób w rzeczywistości oraz w przestrzeni wirtualnej - można dodać dzisiaj - to nic innego jak partycypacja społeczna. I ta powinna być przez dorosłych uznawana, a przez badaczy poznawana, tymczasem dorośli, nagłaśniając potrzebę partycypacji, często nie dostrzegają, umniejszają, dyskryminują znaczeniowo tę „nieformalną” codzienną partycypację dzieci, ich samorzutną aktywność społeczną i wytwarzanie kultury.

Ostatni aspekt, na który chcę zwrócić uwagę, to obszar partycypacji, jakim jest dostęp do dóbr i praw życia politycznego dla dzieci, to ich stowarzyszanie się, tworzenie własnych organizacji zarządzanych przez nich samych lub przy pomocy dorosłych (Johnson, 2009), a wręcz tworzenie prze młodych ludzi ruchów społecznych. Także na tym polu nader często spotyka się dewaluowanie społecznej wartości takich aktywności i form działania dzieci, często brak jest możliwości ich sankcjonowania, występują próby kontrolowania przez dorosłych lub wręcz traktowanie dziecięcego zrzeszania się w kategoriach zagrożenia ładu społecznego.

Wdrażanie koncepcji partycypacji społecznej dzieci jest obecnie traktowane jako imperatyw działań społecznych oraz jako wyraźny kierunek prowadzonej polityki w różnych obszarach społecznych w wielu społeczeństwach. Uważane jest to za konieczny kierunek rozwoju społecznego, a nawet jest traktowane jako miara rozwoju demokracji społeczeństw. „Naród jest demokratyczny w takim stopniu, w jakim jego wszyscy obywatele są uczestnikami życia”, podkreślał kiedyś Roger Hart (1992, s. 4). Nierzadko zauważa się, że upowszechnianie partycypacji społecznej dzieci to działania fundamentalne dla poprawy ogólnej jakości społeczeństw, a wręcz ich przetrwania (Hart, 1992; Levy, 2017). Partycypację dzieci spostrzega się więc też jako drogę odbudowy, naprawy jakości życia społecznego. W tym duchu partycypacja dzieci stała się jedną z centralnych idei społeczno-politycznych, jednym z głównych nurtów myślenia o kierunkach rozwoju społecznego w wielu krajach. Dla jej realizacji na różnych poziomach społecznych, działają liczne agendy i instytucje (Taylor, Percy-Smith, 2008). Jak podaje Gerison Lansdowne (2018) powstało już ponad 200 organizacji w 70 krajach, które działają na rzecz wdrażania w praktykę społeczną lub monitorują realizację praw partycypacyjnych. Ich działalność jest coraz bardziej widoczna na forum międzynarodowym i krajowym. 


\section{DOKĄD ZMIERZA DYSKURS O PARTYCYPACJI? - CZYLI KILKA UWAG NA KONIEC}

Debata o partycypacji społecznej dzieci wyrastała początkowo, jak starałam się to pokazać, z ogólniejszego dyskursu o dzieciństwie i obrazu „nowego” dziecka. Późniejsze perspektywy rozważania tematu partycypacji dzieci wydają się jednak już odzwierciedleniem szerszego trendu widocznego w społeczeństwach zachodnich, polegającego na uznaniu partycypacji za centralną drogę rozumienia i urzeczywistniania demokracji. Dzisiaj akcentuje się wymiar wartości równości i realizacji pełnej demokracji w kontekście udziału w życiu i decydowaniu wszystkich, takżedzieci. W tym świetle partycypacja dzieci, a raczej jej niski poziom, jest wyzwaniem i zadaniem dla urzeczywistniania głębokiego sensu i znaczenia demokracji i realizacji jej zasad obejmujących możliwie pełną inkluzję indywidualną, ale nade wszystko grupową. W tym kontekście partycypacja dzieci jest więc rozważana jako „walka” o uznanie dyskryminowanej (mniejszościowej) grupy społecznej ze względu na wiek, czyli dzieci. Uznanie dzieci jako uczestniczących obywateli. A jednocześnie jest to kontestacja dyskryminowania i społecznego wykluczania dzieci - adultyzmu, jak określa to Liebel (2017a).

Dla pełnej realizacji owego udziału i współdecydowania, prawdziwej partycypacji społecznej dzieci, podkreśla się i dąży do tego, by w dyskurs o niej włączali się sami młodzi ludzie. Aby w pryzmacie dialogu społecznego z dziećmi pogłębiać i eksplorować partycypację młodych jako taką. W konsekwencji chodzi o to, by do monologicznego dotychczas dyskursu o partycypacji młodych uprawianego przez dorosłych odejść w kierunku podejścia dialogowego. Czyli podejścia, które umożliwia włączenie nowych obszarów badawczych i konceptualnych i rozwijanie nowych kierunków dyskursu w partycypacji dzieci z dziećmi! To pozwala na przykład na stawianie nowych pytań, jak chociażby o to, jak naprawdę angażujemy się (jako dorośli) w dialog z dziećmi na temat spraw i rzeczy, które ich dotyczą oraz które je same interesują? Albo pytanie o to, jak radzić sobie z występującym u dzieci brakiem zainteresowania dialogiem, a niekiedy z ich postawami opozycyjnymi wobec proponowanych rozwiązań lub samej propozycji dialogu? Kolejne istotne pytanie to, na ile z szacunkiem i uwagą słyszymy, jak dzieci mówią nam, że coś jest dla nich ważne i rzeczywiście działamy w tym kierunku? I szereg innych podobnych pytań, w tym przecież pytań proponowanych przez same dzieci. Partycypacja dzieci w samym dyskursie o partycypacji, wspólne zastanawianie się może pomóc w budowaniu rzeczywistej wiedzy o partycypacji, jej możliwościach oraz trudnościach, ale też w efekcie może rozwijać partnerskie postawy dorosłych wobec dzieci i w konsekwencji... bardziej sprawiedliwy i przyjazny świat. 


\section{Bibliografia}

Aries, P. (1995). Historia dzieciństwa. Dziecko i rodzina w dawnych czasach. Tłum. M. Ochab. Gdańsk: Wydawnictwo Marabut.

Cockburn, T. (2010). Children and deliberative democracy. W: B. Percy-Smith, N. Thomas (eds.), A Handbook of Children and Young People's Participation. Perspectives From Theory and Practice. New York: OXON, Routledge.

Cockburn, T. (2013). Rethinking children's citizenship. Basingstoke: Palgrave Macmillan.

Cooke, B., Kothari, U. (eds.). (2001). Participation: The New Tyranny? London: Zed Books.

Corsaro, W. (1997). The Sociology of Childhood. London: Pine Forge Press.

Dahl, T. (2014). Children as Researchers: We Have a Lot to Learn. W: G. Melton i in. (eds.), The SAGE Handbook of Child Research. Los Angeles-Washington: SAGE.

Fitzgerald, R., Graham, A., Smith, A., Taylor, N. (2010). Children's Participation as a Struggle over Recognition. W: B. Percy-Smith, N. Thomas (eds.), A Handbook of Children and Young People's Participation. Perspectives From Theory and Practice. New York: OXON, Routledge.

Freire, P. (2005). Pedagogy of the oppressed. 30 Anniversary edition. New York-London: CONTINUUM.

Hart, R. (1992). Children's Participation: from Tokenism to citizenship. Florence: UNICEF. Hart, R. (1997). Children's Participation: The Theory and Practice of Involving Young Citizens in Community Development and Environmental Care. London-New York: Earthscan Publications.

Hart, R. (2009). Charity Change in the Participatory Settings of Childhood. W: N. Thomas (ed.), Children Politics and Communication. Participation at the Margins. Bristol: The Policy Press University of Bristol.

Holt, J. (1974). Escape from childhood: the needs and rights of childhood. New York: Dutton and Co inc.

Jarosz, E. (2008). Ochrona dzieci przed krzywdzeniem. Perspektywa globalna i lokalna. Katowice: Wydawnictwo Uniwersytetu Śląskiego.

Jarosz, E. (2013). Społeczne wykluczenie i dyskryminacja dzieci - marginalizowany obszar nierówności społecznych. Studia Edukacyjne, 24.

Jarosz, E. (2017). Obywatelskość dziecka - wyboista droga emancypacji w warunkach oporu dorosłych. Chowanna, 2, s. 147-172.

Jenks, Ch. (2008). Socjologiczne konstrukty dzieciństwa. W: M.J. Kehily (red.), Wprowadzenie do badań nad dzieciństwem. Kraków: Wydawnictwo WAM.

Johnson, V. (2009). Children's Autonomous Organisation: Reflection from the Ground. W: N. Thomas (ed.), Children, politics and communication. Participation at the margins. University of Bristol: The Policy Press.

Korczak, J. (1928). Wstęp. W: M. Rogowska-Falska, Zakład wychowawczy „Nasz Dom”. Warszawa.

Lansdowne, G. (2010). Addressing the Balance of Power. W: M. Shuurman (ed.), Valuing Children's Potentials: How children's participation contributes to fighting poverty and social exclusion. Brussels: Eurochild.

Lansdowne, G. (2018). Progress and challenges in child participation. W: M. Michalak 
(red.), Prawa dziecka wczoraj, dziś i jutro - perspektywa korczakowska. Warszawa: BRPD.

Levy, J. (2016), Democracy Begins with Children’s Rights. Pedagogika Społeczna, 2.

Liebel, M. (2017a). Adultyzm i dyskryminacja wobec dzieci ze względu na wiek. W: M. Liebel, U. Markowska-Manista, Prawa dziecka w kontekście wielokulturowości. Janusz Korczak na nowo odczytany. Warszawa: Wydawnictwo Akademii Pedagogiki Specjalnej.

Liebel, M. (2017b). Kulturowe wariacje form partycypacji dzieci. W: M. Liebel, U. Markowska-Manista, Prawa dziecka w kontekście międzykulturowości. Janusz Korczak na nowo odczytany. Warszawa: Wydawnictwo Naukowe Akademii Pedagogiki Specjalnej.

Lister, R. (2009). Unpacking Children Citizenship. W: A. Invernizzi, J. Williams (ed.), Children and Citizenship. Los Angeles-Washington: SAGE.

Lundy, L. (2007). "Voice” is not enough: conceptualising article 12 of the United Nations Convention On The Rights Of The Child. British Educational Research Journal, vol 33, issue 6 , pp. 927-942.

Mannion, G. (2004). Beyond the Disneyesque: children's participation, spatiality and adult-child relations. Childhood, Vol. 11, No. 3, pp 303-318.

Mannion, G. (2010). After participation: The socio-spatial performance of intergenerational becoming. W: B. Percy-Smith, N. Thomas (eds.), A Handbook of Children and Young People's Participation. Perspectives From Theory and Practice. New York: OXON, Routledge.

Miller, A. (2009). Zniewolone dzieciństwo. Ukryte źródła tyranii. Tłum. B. Przybyłowska. Poznań: Media Rodzina (Frankfurt am Main 1980, wyd. I).

Milne, B. (2005). Is 'Participation' As It is Described by the United Nations Convention on the Rights of the Child (UNCRC) the Key to Children's Citizenship? W: A. Invernizzi, B. Milne (eds.), Children's Citizenship: An Emergent Discourse on the Right of the Child? Journal of Social Sciences Special Issue, 9, s. 31-42.

Morrow, V. (2005). Social Capital, Community Involvement and Community Cohesionin England: A Space for Children and Young People? Journal of Social Sciences (9), s. 57-69.

O’Toole, T., Gale, R. (2008). Learrning from political sociology: structure, agency and inclusive governance. International Journal of Children's Rights, 16(3), s. 369-378.

Percy-Smith, B. (1998). Children's Participation in Local Decision-Making. The Challenge for Local Governance. W: V. Johnson i in. (eds.), Stepping Forward: Children and Young People's Participation in the Development Process. London: It Publication.

Percy-Smith, B. (2010). Councils, consultation and community: Rethinking the space for children and young people's participation. Children's Geographies, 8(2), s. 107-122. Percy-Smith, B., Thomas, N.(eds.). (2010). A Handbook of Children and Young People's Participation. Perspectives From Theory and Practice. New York: OXON, Routledge. Prawa dziecka. Dokumenty Organizacji Narodów Zjednoczonych (2015). Oprac. P. Jaros, M. Michalak. Warszawa: Biuro Rzecznika Praw Dziecka.

Prout, A., James, A. (eds.). (1997). Constructing and reconstructing Childhood. Contemporary Issues in the sociological study of childhood. London-Washington: Falmer Press. 
Rosen, R., Twamley, K. (eds.). (2018). Feminism and the Politics of Childhood: Friends or Foes?. London: UCLPRESS.

Szczepska-Pustkowska, M. (2011). Od filozofii dzieciństwa do dziecięcej filozofii życia. Casus władzy (i demokracji). Kraków: Impuls.

Śliwerski, B. (2003). Współczesne teorie i nurty wychowania. Kraków: Impuls.

Śliwerski, B. (2007). Pedagogika dziecka. Studium pajdocentryzmu. Gdańsk: GWP.

Taylor, M., Percy-Smith, B. (2008). Children's Participation: Learning from and for Community Development. International Journal of Children's Rights, 16(3).

Taylor, N.J., Smith, A.B. (eds.). (2009). Children as Citizens? International Voices. Dunedin: University of Otago Press.

Thomas, N. (2012). Love, Rights and Solidarity: Studying Children's Participation Using Honneth's Theory of Recognition. Childhood, 19(4), s. 453-466.

Thomas, N. (ed.). (2009). Children, politics and communication. Participation at the margins. University of Bristol: The Policy Press.

Thomas, N. (2007). Towards a Theory of Participation. International Journal of Children's Rights, 15(2).

Tisdall, K. (2010). Governance and participatio. W: B. Percy-Smith, N. Thomas (eds.), A Handbook of Children and Young People's Participation. Perspectives From Theory and Practice. New York: OXON, Routledge.

Toots, A., Worley, N., Skosireva, A. (2014). Children as Political Actors. W: G. Melton $\mathrm{i}$ in. (eds.), The SAGE Handbook of Child Research. Los Angeles-Washington: SAGE.

Worpole, K (2003), No Particular Place to Go? Children, Young People and Public Space. Birmingham: Groundworks UK.

Wyness, M. (2012). Childhood and Society. Wydanie 2. London: Palgrave Macmillan. 